\title{
An Influence of Multiple Drying/Rewetting Cycles upon the Respiration of Organic Forest Soil
}

\author{
Zofia Fischer $(\mathbb{B}$ \\ Institute of Landscape Architecture Catholic University of Lublin, Lublin, Poland \\ Email: zofiaf34@gmail.com
}

How to cite this paper: Fischer, Z. (2019) An Influence of Multiple Drying/Rewetting Cycles upon the Respiration of Organic Forest Soil. Open Journal of Soil Science, 9 , 141-154.

https://doi.org/10.4236/ojss.2019.99009

Received: August 16, 2019

Accepted: September 21, 2019

Published: September 24, 2019

Copyright (อ 2019 by author(s) and Scientific Research Publishing Inc. This work is licensed under the Creative Commons Attribution International License (CC BY 4.0).

http://creativecommons.org/licenses/by/4.0/

\section{(c) (i) Open Access}

\begin{abstract}
It is already known that repeating cycles of drying and rewetting decrease the metabolic activity of the soil. The aim of this paper is to explain on the basis of a laboratory experiment how the respiratory processes of organic soil collected from the forest ecosystem typical for a moderate climate are changing during ten consecutive events of watering, and how alters the relationship between changing humidity of the soil and oxygen consumption/carbon dioxide emission. After 10 cycles, the respiration decreases by 2.4 times however amounts of excreted carbon dioxide and consumed oxygen do not differ between cycles 9 and 10. In successive DRW cycles also the relationship between oxygen consumption/carbon dioxide excretion and humidity level changes. This relationship is logarithmic and the analysis of subsequent regressions indicates the direction of those changes. In successive cycles the value of $\beta$ coefficient (slope) decreases, and both the values of $\beta$ and coefficient $\mathrm{R}^{2}$ are always higher for oxygen consumption that for carbon dioxide excretion. This indicates that processes involving oxygen consumption are always more sensitive to fluctuations of humidity than processes producing carbon dioxide. The optimum of respiration declines in successive DRW cycles.
\end{abstract}

\section{Keywords}

Soil-Water Relationships, Climate Change, Carbon Dioxide Excretion

\section{Introduction}

Climate changes occurring in last decades are undisputable, and their consequences include changes in the humidity of upper soil and fluctuations of the level of ground water. Changes in soil humidity are a significant variable in cli- 
matic system [1], but also influence the functioning of whole ecosystems. Particularly drastic is the current decrease of soil humidity in the northern hemisphere [2]. According to predictions of climatic models, we may expect further intensification of such hydrological cycles in the future i.e. longer dry periods and more intensive rainfalls [3].

A consequence of such hydrological cycles is variable in time amounts of water available for the soil but also changes in the rhythm of its supply. Reaction of soil processes towards fluctuations of soil humidity is very complicated and their coincidence influences whole ecosystems. Therefore the importance of cyclic changes of soil humidity for the regulation of ecosystem functioning may become more important than the total input of water to the soil. Changes in soil humidity affect not only the amount of $\mathrm{CO}_{2}$ emitted from the soil but also other components of carbon cycle in ecosystems [4]. Significant also is the fact that for many forest ecosystems of moderate zone in particular; such meteorological situation is a novelty, since in the past, hydrological cycles were more balanced there. Until now, studies on this problem were mostly concentrated upon arid ecosystems [5] [6]. However it should be taken into account, that climate changes apply as well to ecosystems so far considered as humid, and that so-called "water history" of the soil is a significant factor for the functioning of the whole system [7] [8] [9]. Just because of "water history" moist mixed forests may be more threatened by negative effects of cyclically repeating dry periods [10]. Hence, considering world trends of changes in soil humidity [11], their dangerous effect on forest ecosystems in contemporary zone of moderate climate should be assumed.

In the majority of ecosystems, upper soils are subject from time to time to longer or shorter drying followed by moistening. Always this is a stress for microorganisms inhabiting such soils. They are forced then for the regulation of changing osmotic pressure [8], which is connected with higher energy expenditure and disturbance of normal energy budget. Important may be also the lysis of their cells as a result of a thorough drying up, which would supply then an additional amount of dead organic matter. However, considering the ability of assemblages of microorganisms for survival and adaptation to extreme circumstances like freezing or high temperatures, it can be expected that in conditions of repeatable drying up there is possible some kind of adaptation for cycles of drying and watering [8]. According to Fierer [10] and Evans [8], fluctuations in humidity level may cause a change in taxons of soil microorganisms which would result in simultaneous change of relations between environmental factors and functioning of soil microorganisms. This in turn would influence both: the rate of oxygen consumption and production of carbon dioxide. Emission of $\mathrm{CO}_{2}$ from the soil is a key component of global carbon cycle and equals to $40-70 \mathrm{Pg}$ annually [9]. Similarly, the oxygen consumption by soil microorganisms is also an important part of the global cycle of this element.

While there were numerous papers on the subject of Birch effect and discus- 
sion over this phenomenon still continues [12] [13] [14] [15], the effect of fluctuations of precipitation with quick drying up of the soil has appeared in the centre of interest only recently. Fluctuations in soil moisture reduce the emission of carbon dioxide. Such results were obtained as well in experiments as in field research [4] [13]. However, probably depending on the water history of the ecosystem, this process may have various courses. Considering, that currently in forests of moderate climate cyclic changes of humidity can be expected; important is the knowledge not only on $\mathrm{CO}_{2}$ emission but also on oxygen consumption. There is only few data on this aspect. Nevertheless, both parameters are extremely important for the functioning of the whole ecosystem. An important issue seems to be also an explanation to what extend declines the intensity of metabolic processes in the soil following repeated fluctuations of soil humidity.

The aim of this paper is to answer the question how the metabolic activity of organic soil collected from the ecosystem typical for a moderate climate is changing during ten consecutive events of watering, and how is the relationship between changing humidity of the soil and oxygen consumption/carbon dioxide emission in the course of subsequent cycles.

\section{Material and Methods}

\subsection{The Site and Soil Sampling}

The study was performed with the soil sampled in September 2018 at a mixed forest of Kampinos National Park, situated along the northern neighborhood of Warsaw (Poland) $\left(52^{\circ} 20^{\prime} 212^{\prime \prime} \mathrm{N}, 020^{\circ} 51^{\prime} 260^{\prime \prime} \mathrm{E}\right)$. The climate of the region is of a moderate type, however due to changes occurring recently, basic average values of temperature and precipitation are given in Table 1 (Meteo service: https://www.weatheronline.pl). The sampling site was covered by vegetation in $100 \%$. Dominating tree species there are: alder-Alnus glutinosa (L.), oakQuercus robur L., hornbeam-Carpinus betulus L., Scots pine-Pinus sylvestris L., birch-Betula pendula Roth., maple-Acer platanoides L. The soil there is of histosol type, organic. Samples were collected from a wet site in a dense forest, from the active A1 zone, about $10 \mathrm{~cm}$ below surface of the ground and sifted with $5 \mathrm{~mm}$ sieve. Samples were obtained respecting suggestions by Carter and Gregorich [16].

Table 1. Average data for temperature and precipitation in years 1998-2008-2018 measured at meteorological station Warsaw Okęcie situated some $20 \mathrm{~km}$ from the study area.

\begin{tabular}{rccc}
\hline & 1998 & 2008 & 2018 \\
\hline Max. temperature $\left({ }^{\circ} \mathrm{C}\right)$ & 12.1 & 13.8 & 14.7 \\
Min. temperature $\left({ }^{\circ} \mathrm{C}\right)$ & 4.4 & 5.9 & 6.3 \\
Averaged temperature $\left({ }^{\circ} \mathrm{C}\right)$ & 8.2 & 9.9 & 10.8 \\
Precipitation $(\mathrm{mm})$ & 570.9 & 524.6 & 420.1 \\
\hline
\end{tabular}




\subsection{Laboratory Analyses}

\subsubsection{Humidity}

(GWC-gravimetric water content, WHC—water holding capacity, dm-dry mass)

The applied procedure was based essentially on Grace et al., Priha and Smolander [17] [18] with minor modifications [19]. GWC and other contents are given as ratios, not as percentage. Dry mass was determined by drying soil samples at $110^{\circ} \mathrm{C}$ to constant weight.

\subsubsection{Soil Organic Matter (SOM)}

SOM of soil samples was estimated as loss of weight in ignition to constant weight $(\mathrm{LOI})$ at $500^{\circ} \mathrm{C}$. Organic matter $=\mathrm{LOI}$ was between 0.19 and 0.20 .

\subsubsection{Respiration}

(OCD-oxygen consumption, $\mathrm{PCO}_{2}$ - production of $\mathrm{CO}_{2}$, RQ-respiratory quotient)

To estimate the oxygen consumption and carbon dioxide production, the classic volumetric method using the Scholander type respirometer was applied with minor modifications which are described below in details. The capacity of its cylindrical flasks was $50 \mathrm{ml}$ (inside radius $\mathrm{r}=2 \mathrm{~cm}, \mathrm{~V}=4 \mathrm{~cm}^{2}$ ) and the unit of obtained data was $\mu \mathrm{l} \cdot \mathrm{g}^{-1}$ (dry mass) $\cdot \mathrm{h}^{-1}$. Each experimental series consisted of two parts. In the first, without hydroxide in the flasks, changes in the volumes were recorded mostly for 5 hours, this gave the sum of $\mathrm{CO}_{2}$ changes and $\mathrm{O}_{2}$ consumption, in the second part after placing filter paper soaked with $\mathrm{NaOH}$ solution into the respirometric chamber, recorded was the oxygen consumption (OCD) for another 5 hours interval, with readings each 30 minutes. Such procedure allows for recording even small changes in respiration. The water bath temperature was $17.5^{\circ} \mathrm{C}$. Sensitivity of the volumetric respirometer is effectively not much worse $\left(<0.1 \mu \mathrm{l} \cdot \mathrm{gas} \mathrm{g}^{-1} \cdot\right.$ hour $\left.^{-1}\right)$ than of the IR meters, though rates of providing data are not comparable. Values of OCD were obtained in the second reading (with the use of hydroxide) while $\mathrm{PCO}_{2}$ was calculated as the sum of readings with and without hydroxide, respecting the signs. Then the results were plotted against time of readings, the slope coefficient of the regression $(\beta)$ was the rate $\left(\mathrm{O}_{2}\right.$ consumption-OCD or $\mathrm{PCO}_{2}$ ); the respective regression coefficients were all $\mathrm{r}>$ 0.95 , subsequently corrected for pressure and temperature, multiplied by the calibration factor and related per gram of dry soil and hour. Weights of respiration vials with soil were taken regularly; tare was subtracted to get rates of drying.

\subsection{The Experiment}

The aim of the experiment was a comparison of soil metabolism during 10 consecutive cycles of watering and drying (DRW). Every cycle lasted for 10 days. Drying took place in the temperature fluctuating between $24^{\circ} \mathrm{C}$ do $34^{\circ} \mathrm{C}$. For watering of soil samples the distillate water was used, in amounts exceeding the maximal water holding capacity of the soil (GWC > 1, WHC > 100\%). After 10 
days, the humidity of the soil decreased to $0.37-0.08 \mathrm{GWC}$ and then the sample was watered again. The whole experiment lasted for 120 days. Fluctuations of humidity during the experiment are shown at Figure 1.

Right after sampling of the soil and its sifting, the humidity (GWC), water holding capacity (WHC) and organic matter contents were determined. [16] [17] [18] [19]. Subsequently, 12 respirometric vials were filled up with about 15 $\mathrm{g}$ of dry mass of the soil. The soil in vials was then watered and compress by hand. Respirometry was performed during every second cycle i.e. during cycles: $1,3,5,7,9,10$ designated as A, B, C, D, E, F. During one cycle, respirometric measurements were taken in days: 1, 4, 7 and 10, which allowed during the analysis of data for coupling the obtained results, and on the basis of such acquired curve, summing up both the $\mathrm{CO}_{2}$ production and $\mathrm{O}_{2}$ consumption during the full, 10 days long cycle. Every series of respirometry was performed in 12 vials. In order to skip the Birch effect, the beginning of respirometry was initiated in 3 days after the full watering of the soil. After the completion of the measurement of respirometry vials were opened and left for free drying.

Because of the long time period of the experiment, a part of the soil was separated at the beginning of the experiment, and placed in closed containers in the temperature between $10^{\circ} \mathrm{C}-15^{\circ} \mathrm{C}$. The humidity of the soil in containers was kept at the level of initial humidity determined at the beginning of the experiment. After the end of experiment, GWC, WHC values, organic matter content and respiration were determined for this samples of soil in order to verify whether the soil properties had changed i.e. become degraded during the experiment.

Because as it is seen at Figure 1, the final humidity assumed as ultimate drying, changed between 0.37 - 0.08 GWC (31.55\% - 6.8\% WHC), an additional experiment was set in order to answer the question whether the degree of final drying influences the level of respiration during the subsequent watering. Therefore, 36 vials containing soil samples were divided into 3 groups of 12 vials each, with soil humidity about $80 \%$ of maximal WHC. First 12 samples were dried up to humidity equaling $0.4 \mathrm{GWC}(34.12 \% \mathrm{WHC})$, the second group to $0.2 \mathrm{GWC}$

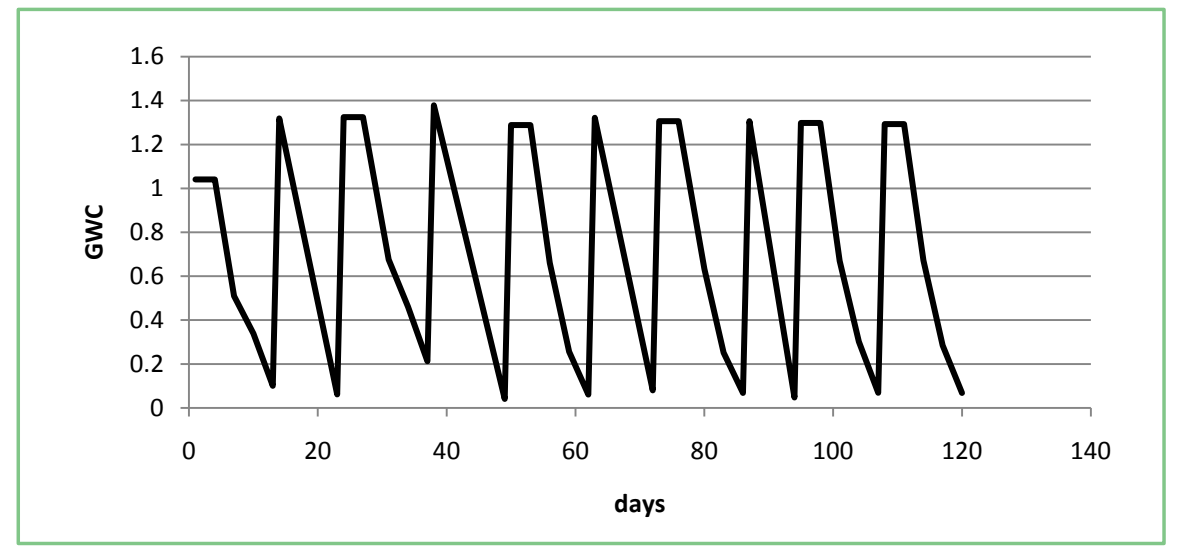

Figure 1. Changes in humidity of the soil (GWC) during the experiment. 
(17.06\% WHC) and the third to humidity of 0.02 GWC (1.70\% WHC). After reaching desired levels of humidity, the respiration level was measured in all samples, then they were watered up to the initial level of humidity and after 3 days the respiration level was determined again in all samples.

\subsection{Statistics}

Means (m), standard deviations (s), coefficients of variation (cv) and standard errors of the mean (se) were determined for all data series. A T-test for equality of means was used to determine the statistical significance of mean differences. All calculations were done with PS Imago Pro 5.1 statistics software.

\section{Results and Discussion}

DRW cycles change the circulation of elements in ecosystems in a drastic way [8] [20] [21] [22], and soil microorganisms both participate in those changes and respond to them [8] [10] [23]. Those reactions depend on the type of the ecosystem, the duration of wet and dry periods, temperature, the volume of precipitation in a studied period and the climatic history of a given region [8] [9] [24] [25] [26]. Numerous studies indicate that assemblages of microorganisms change during repeated DRW cycles and therefore modify their reaction towards changes of humidity [8] [23] [27].

From such broad problem, with a number of mutually conditioned aspects, two issues were selected for the analysis: potential stabilisation of carbon dioxide excretion and oxygen consumption during subsequent DRW cycles and respirometric reaction of the soil towards changes of humidity during DRW cycles. The laboratory experiment was conducted with organic forest soil, without considerable, frequent dry periods in its history, so according to Fierer apparently sensitive to DRW cycles [10]. Despite the fact that the experiment was conducted with a soil concoction from formerly sieved soil, hence with disturbed diffusive structure, so because the soil was not moved during the whole experiment (120 days), obtained results allow for drawing a conclusion about the reaction of the assemblage of microorganisms towards DRW cycles within the range of GWC from the full saturation with water $(\mathrm{GWC}>1)$ until drying $(\mathrm{GWC}<0.3)$.

\subsection{An Influence of Repeating Cycles of Watering and Drying (DRW) upon the Oxygen Consumption and Excretion of Carbon Dioxide from the Soil}

A comparison of an intensity of soil metabolism during consecutive DRW cycles was based upon the sum of consumed oxygen and excreted carbon dioxide by one gram of dry mass of the soil during every 10-day cycle. This cumulation was performed assuming that an intensity of soil metabolism changes according to a curve obtained from 4 readings carried out during every each cycle of drying. Such calculations were done for each of 12 respirometers and an average value was determined. Those results are presented in Figure 2. Simultaneously, from 
all data $(n=74)$ the regressions of the relationship between consumed oxygen and excreted carbon dioxide and consecutive DRW cycles during the whole experiment i.e. all subsequent cycles of drying were calculated. The equations of these regressions are as follows:

$$
\begin{gathered}
\text { OCD } y=-0.847 x+13.701, R^{2}=0.629, p=0.000, n=74 ; \\
\text { PCO } 2 y=-0.570 x+9.486, R^{2}=0.61, p=0.000, n=74 .
\end{gathered}
$$

Both regressions are descending, highly significant and explicitly confirm the decreasing intensity of soil metabolism together with subsequent cycles of drying. A declining excretion of carbon dioxide under the influence of DRW was observed for many various soils but reasons for this phenomenon are uncertain [23] [25] [26]. An influence of DRW upon the excretion of carbon dioxide from the soil seems to be unquestionable however not univocal are the direction and intensity of those changes [10] [25] which depend among other factors from the duration of observation, mostly because of so called Birch effect. It is worth to mention that in this experiment, changes in first $72 \mathrm{hrs}$ after immersion of the soil in the water were intentionally neglected in order to mitigate Birch effect [27].

The slope of the regression describing the relationship between the carbon dioxide excretion and subsequent DRW cycles is somewhat lesser than that for oxygen consumption, which obviously causes that RQ value for the last cycle is higher $(\mathrm{RQ}=0.74)$ than for the first $(\mathrm{RQ}=0.70)$. Unfortunately, because of the high dispersion of RQ values, statistical comparison of mean values does not provide a univocal result. However, the significance of differences between mean values of oxygen consumption and carbon dioxide excretion for subsequent cycles is presented in Table 2. According to both Figure 2 and Table 1, oxygen consumption is the higher at the beginning of experiment and is significantly different from its values in every successive cycle. Only the fifth cycle of watering (C) is not different from the seventh (D) similarly like two last cycles. This suggests that oxygen respiration of the soil after multiple watering and drying is reaching a low level but becomes stable. The reaction of carbon dioxide excretion is different. Every cycle causes its decrease (Figure 2), but statistically significant difference among mean values, is visible only in a comparison with a cycle in a further sequence. Similarly like in the case of oxygen consumption the lack of significant differences occurs between two last cycles. The rate of both processes decreases by 2.3 times during experimental 10 DRW cycles.

During natural hot summer with tempestuous rainfalls, not always, especially in the forest the soil may dry out up to GWC 0.1, just like it was set in described experiment. Taking into account results obtained by Meisner [28] which proved an influence of a degree of drying out of the soil upon the growth of bacteria after its watering, a control experiment was carried out. It proved the lack of statistical differences between the respiration of the soil dried out until the humidity values of $0.4,0.2,0.02 \mathrm{GWC}$ and subsequently watered up to $0.77 \mathrm{GWC}$. It 


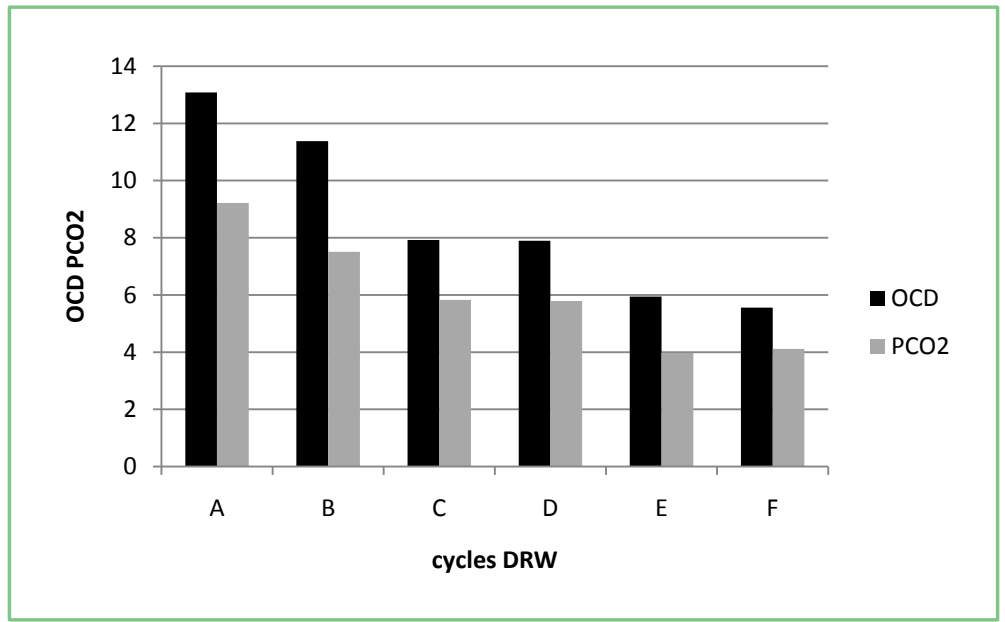

Figure 2. Mean values $(\mathrm{n}=12)$ of changes in summarized oxygen consumption and carbon dioxide excretion $\left(\mu \mathrm{l} \cdot \mathrm{g}[\mathrm{dm}]^{-1}\right)$ during subsequent 10 days long cycles.

Table 2. Significance of differences between mean values of oxygen consumption. ${ }^{\star}$ and carbon dioxide excretion. ${ }^{* *}$ during subsequent 10 days cycles of drying.

\begin{tabular}{ccccccc}
\hline cycles & $\mathrm{A}$ & $\mathrm{B}$ & $\mathrm{C}$ & $\mathrm{D}$ & $\mathrm{E}$ & $\mathrm{F}$ \\
\hline $\mathrm{A}$ & $\mathrm{x}$ & $0.042^{*}$ & $0.000^{*}$ & $0.000^{*}$ & $0.000^{*}$ & $0.000^{*}$ \\
$\mathrm{~B}$ & $0.078^{* *}$ & $\mathrm{x}$ & $0.007^{*}$ & $0.000^{*}$ & $0.000^{*}$ & $0.000^{*}$ \\
$\mathrm{C}$ & $0.002^{* *}$ & $0.147^{* *}$ & $\mathrm{x}$ & $0.331^{*}$ & $0.001^{*}$ & $0.000^{*}$ \\
$\mathrm{D}$ & $0.000^{* *}$ & $0.018^{* *}$ & $0.218^{* *}$ & $\mathrm{X}$ & $0.001^{*}$ & $0.000^{*}$ \\
$\mathrm{E}$ & $0.000^{* *}$ & $0.000^{* *}$ & $0.000^{* *}$ & $0.000^{* *}$ & $\mathrm{x}$ & $0.356^{*}$ \\
$\mathrm{~F}$ & $0.000^{* *}$ & $0.000^{* *}$ & $0.000^{* *}$ & $0.000^{* *}$ & $0.569^{* *}$ & $\mathrm{x}$ \\
\hline
\end{tabular}

should be assumed that the divergence between presented results and data of Meisner results from the fact, that Meisner conducted his experiments during first hours after watering of the dry soil while in this experiment, first $72 \mathrm{hrs}$ were neglected. In the beginning and the end of the experiment also the organic matter contents and WHC value were determined. Applied methodology did not found changes in the organic matter contents but this does not mean that there was no alteration of the composition of organic matter. The WHC value did not significantly change.

Therefore presumably, that if during a hot summer torment rainfalls occur, the intensity of metabolism of soil microorganisms significantly decreases and become stable at low level. The decline of both: oxygen consumption and carbon dioxide excretion indicates very serious disturbance in the activity of destruents, which must result in alteration of carbon cycle in the whole ecosystem.

\subsection{A Relationship between Changing Humidity of the Soil and Oxygen Consumption/Carbon Dioxide Excretion during Subsequent Cycles of Drying/Watering}

The reaction of metabolic activity of soil microorganisms for changes in soil 
humidity is very important but often underestimated trait regarding both aspects: functioning of an ecosystem i.e. the activity of destruents in changing climate as well as climatic models [9] [29]. Considering intensifying conditions of water deficit, water holding capacity (WHC) is closely connected with that issue and not less important. This parameter to a great extend is decisive regarding the availability of water and air to soil organisms and is changing seasonally since its value depends on the inflow of organic matter and the system of humidification of the soil [19].

The WHC of soil used for this experiment was not high $(\mathrm{WHC}=1.1723$; $\mathrm{sd}=$ 0.0823 ; se $=0.02744 \mathrm{p}=0.000$ ). For such forests this value is rather low. In 2014 the maximal WHC value for soils sampled in the same site ranged between 0.5 and $>4[19]$.

It was demonstrated that under an influence of DRW cycles, assemblages of microorganisms change their associations and also display various reactions towards humidity of the soil [10] [29]. The relationship between decreasing humidity and carbon dioxide excretion/oxygen consumption is the most similar to sinusoid, assuming that initial humidity considerably exceeds the maximal value. Theoretically it is accepted that the optimum of aerobic respiration occurs at humidity of about $0.6 \mathrm{GWC}$ which results from diffusive properties of the soil, which influence availability of water and oxygen for living organisms [30] [31]. However, since in the nature, the assemblages of microorganisms live in very different and complicated environmental conditions, both the optimum of respiratory activity of the soil and the character of metabolic reaction for fluctuations of humidity are changeable and provide a lot of information about the adaptation of living organisms to actual conditions. In this experiment, at humidity ranging between 0.08 GWC (6.82\% WHC) and over 1 GWC (100\% WHC), the optimum of respiration was different for the excretion of carbon dioxide and oxygen consumption and ranged from the value over $1 \mathrm{GWC}$ to $0.6 \mathrm{GWC}$ (Figure 3). The relationship between the humidity and oxygen consumption/carbon dioxide excretion followed the logarithmic regression for all DRW cycles. Equations of regression for every cycle and differences between them are given in $\mathrm{Ta}$ ble 3. Two first cycles had high " $\beta$ " values, reflecting the slope of the curve i.e. a sharp reaction of metabolic activity for changes in humidity. Statistical probability of all regressions is high $(p=0.000)$, however the determination coefficient $R^{2}$ is changing. According to Meisner [27] [28] [32], depending on the rate of reaction for increasing humidity, two groups of microbial assemblages can be identified: resistant and less resistant for changes of humidity. According to this theory, less resistant microbial assemblages initiate their growth after a longer lime since humidification. The A and B DRW cycles have their optimum at the beginning of experiment. For both: oxygen consumption and carbon dioxide excretion it exceeds $1 \mathrm{GWC}$, so its value is high, however the optimum is not very distinct (Figure 3). If the theory of Meisner would be generalized beyond the Birch effect, assuming that microbial assemblages less resistant for humidity 

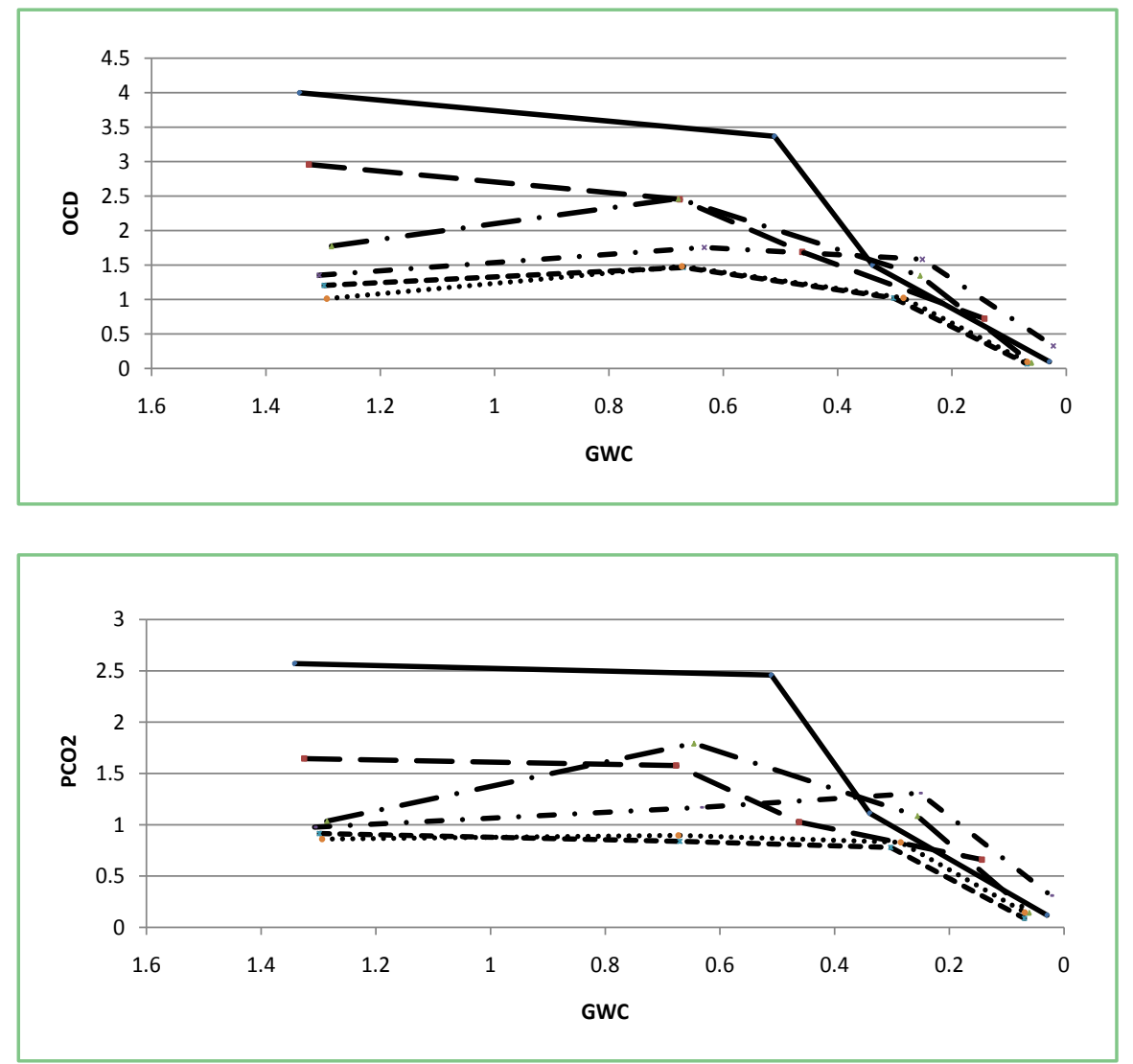

Figure 3. Changes of OCD and PCO2 values (both as $\mu \mathrm{l} \cdot \mathrm{g}[\mathrm{dm}]^{-1} \cdot \mathrm{h}^{-1}$ ) in changing humidity during subsequent cycles of drying, every point $\mathrm{n}=12$; cycle $\mathrm{A}-\mathrm{B}--\mathrm{C}-.-\mathrm{D}$ -.- E ---- F ....

Table 3. Equations of regression for the relationship between oxygen consumption/carbon dioxide excretion and humidity during subsequent cycles. For each regression $n=48$.

\begin{tabular}{|c|c|c|c|c|}
\hline Cycles & & & \multicolumn{2}{|c|}{$\mathrm{PCO}_{2}$} \\
\hline \multirow{2}{*}{ A } & \multicolumn{2}{|c|}{$y=1.7346 \ln (x)+3.9861$} & \multicolumn{2}{|c|}{$y=1.1277 \ln (x)+2.6979$} \\
\hline & $\mathrm{R}^{2}=0.8334$ & $\mathrm{p}=0.000$ & $\mathrm{R}^{2}=0.6894$ & $\mathrm{p}=0.000$ \\
\hline \multirow{2}{*}{ B } & \multicolumn{2}{|c|}{$y=1.0348 \ln (x)+2.6621$} & \multicolumn{2}{|c|}{$y=0.5048 \ln (x)+1.5631$} \\
\hline & $\mathrm{R}^{2}=0.7239$ & $\mathrm{p}=0.000$ & $\mathrm{R}^{2}=0.48$ & $\mathrm{p}=0.000$ \\
\hline \multirow{2}{*}{$\mathrm{C}$} & \multicolumn{2}{|c|}{$y=0.6811 \ln (x)+2.1631$} & \multicolumn{2}{|c|}{$y=0.3967 \ln (x)+1.4491$} \\
\hline & $\mathrm{R}^{2}=0.577$ & $\mathrm{p}=0.000$ & $\mathrm{R}^{2}=0.4335$ & $\mathrm{p}=0.000$ \\
\hline \multirow{2}{*}{$\mathrm{D}$} & \multicolumn{2}{|c|}{$y=0.3959 \ln (x)+1.6663$} & \multicolumn{2}{|c|}{$y=0.2425 \ln (x)+1.1911$} \\
\hline & $\mathrm{R}^{2}=0.4022$ & $\mathrm{p}=0.000$ & $\mathrm{R}^{2}=0.3159$ & $\mathrm{p}=0.000$ \\
\hline \multirow{2}{*}{$\mathrm{E}$} & \multicolumn{2}{|c|}{$y=0.4088 \ln (x)+1.3613$} & \multicolumn{2}{|c|}{$y=0.262 \ln (x)+0.9258$} \\
\hline & $\mathrm{R}^{2}=0.5689$ & $\mathrm{p}=0.000$ & $\mathrm{R}^{2}=0.5844$ & $\mathrm{p}=0.000$ \\
\hline \multirow{2}{*}{$\mathrm{F}$} & \multicolumn{2}{|c|}{$y=0.3458 \ln (x)+1.2696$} & \multicolumn{2}{|c|}{$y=0.2332 \ln (x)+0.9309$} \\
\hline & $\mathrm{R}^{2}=0.4777$ & $\mathrm{p}=0.000$ & $\mathrm{R}^{2}=0.5047$ & $\mathrm{p}=0.000$ \\
\hline
\end{tabular}


changes react with delayed activity, the cycles A and B should be regarded as that of resistant assemblage because they react for increased humidity quickly with intensified metabolic activity. The cycle $\mathrm{C}$ shows the optimum of respiration at humidity of about 0.6 while the next cycle $\mathrm{D}$ at humidity of about 0.2 . Hence in subsequent cycles of drying, the optimum of respiration occurs in decreasing humidity. The C DRW cycle seems to be the transitional one, in following cycles the coefficient " $\beta$ ' decreases, and the reaction of respiration for successive drying becomes weaker and more stable. The respiration in two last cycles is practically no different. Assuming that coefficient " $\beta$ " describes the rate of reaction of microbial assemblage for humidity changes, it is possible to say that in all DRW cycles the excretion of carbon dioxide always reacts slower for changes of humidity than oxygen consumption. Also the determination coefficient $R^{2}$ is always lower in regressions concerning excretion of carbon dioxide. Considering results presented in Table 2 it is possible to conclude, that the process of oxygen consumption is more sensitive for humidity changes than the production of carbon dioxide. Recently frequent torment rains in Central Europe, during high temperatures moisten mostly the upper layer of the soil, i.e. the layer where oxygen processes dominate and which is the most sensitive to changes of humidity. This layer though is responsible for the circulation of gasses in the soil and therefore for processes regulating the carbon cycle in ecosystems.

\section{Conclusions}

A laboratory experiment with organic forest soil from Central Europe has proved that both the excretion of carbon dioxide and oxygen consumption decreases significantly under an influence of cycles of drying and subsequent rapid rewetting (Table 2). After 10 cycles, the respiration decreases by 2.4 times however amounts of excreted carbon dioxide and consumed oxygen do not differ between cycles 9 and 10.

In successive DRW cycles also changes the relationship between oxygen consumption/carbon dioxide excretion and humidity level. This relationship is logarithmic and the analysis of subsequent regressions indicates the direction of those changes. During first cycles of rewetting the respiration responds with a sharp slope of the curve ( $\beta$ coefficient for $\mathrm{OCD}=1.73 ; 1.03$; for $\mathrm{CO}_{2}=1.12$; 0.50 ). In successive cycles the value of $\beta$ coefficient (slope) decreases and both: the values of $\beta$ and coefficient $\mathrm{R}^{2}$ are always higher for oxygen consumption that for carbon dioxide excretion. This indicates that processes involving oxygen consumption are always more sensitive than processes producing carbon dioxide. The optimum of respiration declines in successive DRW cycles.

Obtained results provide evidence that increasing hot periods with accompanying torment rains may substantially change sensitive organic forest soils which in turn affects the rate of decomposition of organic matter. This disturbs whole forest ecosystems which, especially in the period of global climatic changes, are among the most important reservoirs able for fixation of carbon dioxide from the atmosphere. 


\section{Acknowledgements}

I would like to thank Professor Kajetan Perzanowski for his constructive comments and considerable advice, which were very helpful in this work.

\section{Conflicts of Interest}

The author declares no conflicts of interest regarding the publication of this paper.

\section{References}

[1] Robock, A., Vinnikov, K.Y., Srinivasan, G., Entin, J.K., Hollomger, S.E., Speranskaya, N.A., Liu, S. and Namkhai, A. (2000) The Global Soil Moisture Data Bank. Bulletin of the American Meteorological Society, 81, 1281-1299. https://doi.org/10.1175/1520-0477(2000)081<1281:TGSMDB>2.3.CO;2

[2] Fan, Y. and van den Dool, H. (2004) Climate Prediction Center Global Monthly Soil Moisture Data Set at $0.5^{\circ}$ Resolution for 1948 to Present. Journal of Geophysical Research, 109, D10102. https://doi.org/10.1029/2003JD004345

[3] Huntington, T.G. (2006) Evidence for Intensification of the Global Water Cycle: Review and Synthesis. Journal of Hydrology, 319, 83-95. https://doi.org/10.1016/j.jhydrol.2005.07.003

[4] Harper, C.W., Blair, J.M., Fay, P.A., Knapp, A.K. and Carlisle, J.D. (2005) Increased Rainfall Variability and Reduced Rainfall Amount Decreases Soil $\mathrm{CO}_{2}$ Flux in a Grassland Ecosystem. Global Change Biology, 11, 322-334.

https://doi.org/10.1111/j.1365-2486.2005.00899.x

[5] Collins, S.L., Sinsabaugh, R.L., Crenshaw, C., Green, L., Porras-Alfaro, A., Stursova, M. and Zeglin, L.H. (2008) Pulse Dynamics and Microbial Processes in Aridland. Ecosystems Journal of Ecology, 96, 413-420. https://doi.org/10.1111/j.1365-2745.2008.01362.x

[6] Rey, A., Oyonarte, C., Morán-López, T., Raimundo, J. and Pegoraro, E. (2016) Changes in Soil Moisture Predict Soil Carbon Losses upon Rewetting in a Perennial Semiarid Steppe in SE Spain. Geoderma, 287, 135-146. https://doi.org/10.1016/j.geoderma.2016.06.025

[7] Schwinning, S., Sala, O.E., Loik, M.E. and Ehleringer, J.R. (2004) Thresholds, Memory, and Seasonality: Understanding Pulse Dynamics in Arid/Semi-Arid Ecosystems. Oecologia, 141, 191-193. https://doi.org/10.1007/s00442-004-1683-3

[8] Evans, S.E. and Wallenstein, M.D. (2012) Soil Microbial Community Response to Drying and Rewetting Stress: Does Historical Precipitation Regime Matter? Biogeochemistry, 109,101-116. https://doi.org/10.1007/s10533-011-9638-3

[9] Hawkes, C.V., Warin, B.G., Rocca, J.D. and Kivlin, S.N. (2017) Historical Climate Controls Soil Respiration Responses to Current Soil Moisture. Proceedings of the National Academy of Sciences of the United States of America, 114, 6322-6327. https://doi.org/10.1073/pnas.1620811114

[10] Fierer, N., Schimel, P. and Holden, P.A. (2003) Influence of Drying-Rewetting Frequency on Soil Bacterial. Microbial Ecology, 45, 63-71.

https://doi.org/10.1007/s00248-002-1007-2

[11] Sheffield, J. and Wood, E.F. (2007) Characteristics of Global and Regional Drought, 1950-2000: Analysis of Soil Moisture Data from Off-Line Simulation of the Terrestrial Hydrologic Cycle. Journal of Geophysical Research, 112, D17115. 
https://doi.org/10.1029/2006JD008288

[12] Jarvis, P., Rey, A., Petsikos, C., Wingate, L., Rayment, M., Pereira, J., Banza, J., David, J., Miglietta, M., Manca, G. and Valentini, R. (2007) Drying and Wetting of Mediterranean Soils Stimulates Decomposition and Carbon Dioxide Emission: The "Birch Effect”. Tree Physiology, 27, 929-940.

https://doi.org/10.1093/treephys/27.7.929

[13] Fierer, N. and Schimel, J.P. (2003) A Proposed Mechanism for the Pulse in Carbon Dioxide Production Commonly Observed Following the Rapid Rewetting of a Dry. Soil Science Society of America Journal, 67, 798-805. https://doi.org/10.2136/sssaj2003.0798

[14] Evans, S., Dieckmann, U., Franklin, O. and Kaiser, C. (2016) Synergistic Effects of Diffusion and Microbial Physiology Reproduce the Birch Effect in a Micro-Scale Model. Soil Biology \& Biochemistry, 93, 28-37. https://doi.org/10.1016/j.soilbio.2015.10.020

[15] Waring, B.G. and Powers, J.S. (2016) Unraveling the Mechanisms Underlying Pulse Dynamics of Soil Respiration in Tropical Dry Forests. Environmental Research Letters, 11, Article ID: 105005. https://doi.org/10.1088/1748-9326/11/10/105005

[16] Carter, M.R. and Gregorich, E.G. (2008) Soil Sampling and Methods of Analysis. CRC Press, Taylor \& Francis Group, Boca Raton, FL.

[17] Grace, C., Hart, M. and Brookes P.C. (2006) Laboratory Manual of the Soil Microbial Biomass Group. Rothamsted Research.

[18] Priha, O. and Smolander, A. (2003) Short-Term Uptake of 15NH4 into Soil Microbes and Seedlings of Pine, Spruce and Birch in Potted Soils. Biology and Fertility of Soils, 37, 324-327.

[19] Blazka, P. and Fischer, Z. (2014) Moisture, Water Holding, Drying and Wetting in Forest Soils. Open Journal of Soil Science, 4, 174-184.

https://doi.org/10.4236/ojss.2014.45021

[20] Kim, D.G., Vargas, R., Bond-Lamberty, B. and Turetsky, M.R. (2012) Effects of Soil Rewetting and Thawing on Soil Gas Fluxes: A Review of Current Literature and Suggestions for Future Research. Biogeosciences, 9, 2459-2483.

https://doi.org/10.5194/bg-9-2459-2012 https://www.biogeosciences.net/9/2459/2012/

[21] Pezzolla, D., Cardenas, L.M., Mian, I.A., Carswell, A., Donovan, N., Mewa, S., Dhanoa, M.S. and Blackwell, M.S.A. (2019) Responses of Carbon, Nitrogen and Phosphorus to Two Consecutive Drying-Rewetting Cycles in Soils. Journal of Plant Nutrition and Soil Science, 182, 217-228. https://doi.org/10.1002/jpln.201800082

[22] Borken, W. and Matzner, E. (2009) Reappraisal of Drying and Wetting Effects on C and N Mineralization and Fluxes in Soils. Global Change Biology, 15, 808-824. https://doi.org/10.1111/j.1365-2486.2008.01681.x

[23] Fierer, N. and Schimel, P. (2002) Effects of Drying-Rewetting Frequency on Soil Carbon and Nitrogen Transformations. Soil Biology and Biochemistry, 34, 777-787. https://doi.org/10.1016/S0038-0717(02)00007-X

[24] Shi, A. and Marschner, P. (2015) The Number of Moist Days Determines Respiration in Drying and Rewetting Cycles. Biology and Fertility of Soils, 51, 33-41. https://doi.org/10.1007/s00374-014-0947-2

[25] Li, J.T., Wang, J.J., Zeng, D.H., Ahao, S.Y., Huang, W.L., Sun, Z.K. and Hu, Y.L. (2018) The Influence of Drought Intensity on Soil Respiration during and after Multiple Drying-Rewetting Cycles. Soil Biology and Biochemistry, 127, 83-89. 
https://doi.org/10.1016/j.soilbio.2018.09.018

[26] Yu, Z., Wang, G. and Marschner, P. (2014) Drying and Rewetting-Effect of Frequency of Cycles and Length of Moist Period on Soil Respiration and Microbial Biomass. European Journal of Soil Biology, 62, 132-137.

https://doi.org/10.1016/j.ejsobi.2014.03.007

[27] Meisner, A., Rousk, J. and Baath, E. (2015) Prolonged Drought Changes the Bacterial Growth Response to Rewetting. Soil Biology and Biochemistry, 88, 314-322. https://doi.org/10.1016/j.soilbio.2015.06.002

[28] Meisner, A., Leizeaga, A., Rousk, J. and Baath, E. (2017) Partial Drying Accelerates Bacterial Growth Recovery to Rewetting. Soil Biology and Biochemistry, 112, 269-276. https://doi.org/10.1016/j.soilbio.2017.05.016

[29] de Nijs, E.A., Hicks, L.C., Leizeaga, A., Tietena, A. and Rousk, J. (2018) Soil Microbial Moisture Dependences and Responses to Drying-Rewetting: The Legacy of 18 Years Drought. Global Change Biology, 25, 1005-1015. https://doi.org/10.1111/gcb.14508

[30] Skopp, J., Jawson, M.D. and Doran, J.W. (1990) Steady-State Aerobic Microbial Activity as a Function of Soil Water Content. Science Society of America Journal, 54, 1619-1625. https://doi.org/10.2136/sssaj1990.03615995005400060018x

[31] Oertel, C., Matschullat, J., Zurba, K., Zimmermann, F. and Erasmi, S. (2016) Greenhouse Gas Emissions from Soils-A Review. Geochemistry, 76, 327-352. https://doi.org/10.1016/j.chemer.2016.04.002

[32] Meisner, A., Baath, E. and Rousk, J. (2013) Microbial Growth Responses upon Rewetting Soil Dried for Four Days or One Year. Soil Biology and Biochemistry, 66, 188-192. https://doi.org/10.1016/j.soilbio.2013.07.014 